\title{
Potensi Ekstrak Daun Tembelekan Lantana camara sebagai Penghambat Tumbuh Bakteri pada Rumput Laut Kappaphycus alvarezii
}

\section{Bacterial growth inhibition potential of Leaves Extract Lantana camara on Seaweed Kappaphycus alvarezii}

\author{
Emand Syapriawan Tolanamy $^{1 *}$, Rahmad Sofyan Patadjai ${ }^{2)}$, Indriyani Nur ${ }^{2)}$ \\ 1) Mahasiswa Program Studi Magister Ilmu Perikanan Pascasarjana Univ. Halu Oleo \\ ${ }^{2)}$ Fakultas Perikanan dan Ilmu Kelautan Universitas Haluo Oeo \\ Corresponding authors*): emand.st28@gmail.com; indri_noer@yahoo.com; r.sofyanpatadjai@gmail.com
}

\begin{abstract}
One of the main obstacles in the effort to increase production of seaweed culture, especially of the species Kappaphycus alvarezii are poor water environment quality and very high intensity of seaweed diseases. The aims of this study are to know the secondary metabolite content and the ability of Lantana camara leaf extract in preventing and reducing the rate of disease-causing bacteria transmission in the seaweed thallus by in vitro and cohabitation methods. The results showed that the leaf extract positively contained saponins, tannins, phenolics, flavonoids, steroids, and glycosides Leaf extract solution with a concentration of 2000 ppm could inhibit the growth of Vibrio alginolyctus bacteria cause ice-ice by in vitro method. Submersion treatment for 60 minutes was able to suppress the ability of pathogens transmitting than submersion for 30 and 90 minutes by cohabitation method.
\end{abstract}

Key words: Kappaphycus alvarezii, Lantana camara, Vibrio alginolyctus, ice-ice disease

\begin{abstract}
ABSTRAK
Salah satu kendala utama dalam upaya peningkatan produksi budidaya rumput laut terutama dari jenis Kappaphycus alvarezii adalah perubahan kualitas lingkungan perairan dan intensitas serangan penyakit rumput laut sangat tinggi. Penelitian ini bertujuan untuk mengetahui kandungan senyawa metabolit sekunder dan menguji kemampuan larutan ekstrak daun tembelekan Lantana camara dalam mencegah dan mengurangi tingkat transmisi bakteri penyebab penyakit ice-ice pada thallus rumput laut $K$. alvarezii secara in vitro dan kohabitasi. Hasil penelitian menunjukkan larutan ekstrak daun tembelekan positif mengandung saponin, tanin, fenolik, flavonoid, steroid, dan glikosida. Ekstrak pada konsentrasi 2000 ppm dapat menghambat pertumbuhan bakteri Vibrio alginolyctus penyebab ice-ice secara in vitro. Perlakuan perendaman selama 60 menit lebih mampu menekan kemampuan transmisi bakteri patogen pada pengujian secara kohabitasi dibandingkan perendaman selama 30 dan 90 menit.
\end{abstract}

Kata Kuncis: Kappaphycus alvarezii, Lantana camara, Vibrio alginolyctus, penyakit ice-ice

DOI: http://dx.doi.org/10.33772/jspi.v1n1.xxxx

\section{PENDAHULUAN}

Salah satu komoditas usaha budidaya di perairan Sulawesi Tenggara adalah rumput laut. Hal ini dikarenakan lokasi budidaya yang tersedia sangat luas, teknologi budidaya sangat sederhana, waktu pemeliharaan yang singkat, dan modal yang dibutuhkan relatif kecil. Sulawesi Tenggara termasuk provinsi dengan tingkat produksi rumput laut terbesar keempat di Indonesia yaitu 348.981 ton atau sekitar 8,93\% (DJPB, 2010). Perkembangan produksi rumput laut dari tahun 2010-2014 secara nasional 
menunjukkan pertumbuhan yang sangat positif, dengan kenaikan rata-rata per tahun mencapai 27,72\% (KKP, 2014).

Walaupun produksi terbilang besar akan tetapi masih memiliki beberapa kendala dalam peningkatan kapasitas produksinya. Salah-satu kendala utama upaya peningkatan produksi budidaya rumput laut terutama dari jenis Kappaphycus alvarezii adalah intensitas serangan penyakit yang sangat tinggi. Penurunan produksi budidaya rumput laut berkisar dari 70\%-100\% akibat serangan dari bakteri patogen rumput laut yang terjadi di beberapa negara produsen rumput laut salah satunya di Indonesia (Vairappan $d k k .2008)$.

Beberapa penelitian yang menyatakan bahwa bakteri merupakan salah satu penyebab penyakit iceice diantaranya adalah Largo $d k k$. (1995) dan Aris (2011) yang menyebutkan bahwa bakteri yang memiliki tingkat patogenisitas dan memberikan respon terhadap laju penurunan tertinggi pada thallus rumput laut adalah Vibrio alginolyticus. Potensi tanaman sebagai bahan obat terus berkembang dengan kemampuan kerjanya tidak saja pada satu spesies bakteri patogen tetapi juga bekerja pada bakteri patogen yang sudah resisten terhadap pengobatan menggunakan antibiotik secara kimiawi (Vaseeharan dkk., 2011). Barreto $d k k$. (2010) menyatakan bahwa, ekstrak etanol daun tembelekan memiliki kandungan antibakterial. Hal tersebut dikarenakan pada daun tembelekan memiliki senyawa metabolit sekunder yang dapat menghambat pertumbuhan bakteri diantaranya fenol, flavanoid, terpenoid dan minyak atsiri.

Selain dengan metode pencegahan penyakit pada rumput laut yang selama ini telah dilakukan dengan melakukan pengecekan dan pembersihan thallus rutin ke lokasi budidaya, dipandang perlu ditambahkan metode pencegahan dini terhadap serangan penyakit salah satunya yaitu perlakuan perendaman larutan bahan herbal pada bibit sebelum dilakukan penanaman. Dalam rangka mengoptimalkan pemanfaatan potensi kandungan metabolit sekunder bahan herbal, tembelekan sebagai antibakteri merupakan salah satu alternatif yang perlu diterapkan.

Tujuan dari penelitian ini adalah memeriksa kandungan metabolit sekunder daun tembelekan, lalu menguji daya hambat larutan metabolit sekunder tersebut secara in vitro terhadap bakteri $V$. alginolyticus, kemudian dilanjutkan pengujian kemampuan transmisi bakteri secara kohabitasi dalam wadah terkontrol.

\section{METODE PENELITIAN}

Penelitian ini dilaksanakan pada bulan Mei hingga September 2015. Materi yang digunakan dalam penelitian ini adalah daun tembelekan $L$. camara, isolat bakteri $V$. alginolyctus koleksi Stasiun Karantina Ikan dan Pengendalian Mutu (SKIPM) Ranomeeto, serta bibit rumput laut dari lokasi budidaya perairan Lemobajo, Konawe Utara. Ekstraksi dan analisis skrining kualitatif fitokimia daun tembelekan (L. camara) dilaksanakan di Laboratorium Balai Penelitian Tanaman Rempah dan Obat-obatan (Balitro) Bogor. Uji hambat tumbuh bakteri secara in vitro dan in vivo dalam akuarium dilaksanakan di Laboratorium Perikanan, Fakultas Perikanan dan Ilmu Kelautan, Universitas Halu Oleo (F-PIK UHO) Kendari.

Metode yang digunakan dalam penelitian ini adalah eksperimental laboratoris. Analisis data hasil pengamatan uji hambat secara in vitro dan perubahan berat thallus terinfeksi bakteri patogen hasil uji kohabitasi diolah dengan analisis deskriptif dalam bentuk gambar, tabel, dan grafik.

Data hasil interaksi pengaruh masingmasing perlakuan penelitian pada uji in vitro dianalisis menggunakan T-Test dan untuk uji kohabitasi ditentukan dengan Analysis of Varians (Anova), selanjutnya adanya signifikansi (sig < 0,05) interaksi antara perlakuan ditentukan dengan uji lanjut Tukey Honestly Significant Different (HSD) dengan bantuan Statistical Program Software System (SPSS) versi 16 pada tingkat kepercayaan $95 \%$.

\section{Pengeringan Daun Tembelekan}

Daun yang telah diperoleh lalu disortir untuk memisahkan daun dari batang yang masih tersisa. Daun hasil sortiran yang telah bersih kemudian dikeringanginkan selama 4 (empat) hari dilanjutkan dalam oven bersuhu konstan $40{ }^{\circ} \mathrm{C}$ selama 3 (tiga) hari. Daun yang telah dibuat ke dalam bentuk sediaan kering (simplisia) ini dapat diketahui dengan cara diremas akan segera patah dan hancur.

\section{Ekstraksi (Harborne, 1987)}

Ekstraksi dilakukan dengan menggunakan ekstraksi padat-cair metode maserasi dengan pelarut semipolar yaitu etanol $96 \%$. Perbandingan pelarut 
dengan sampel 4:1. Serbuk yang telah dimaserasi menggunakan selama 72 jam lalu difiltrasi dengan corong Buchner untuk memperoleh filtrat. Filtrat yang diperoleh kemudian dipekatkan dengan menggunakan rotary evaporator pada suhu maksimal $60{ }^{\circ} \mathrm{C}$ hingga pelarut etanol menguap dan terbentuk ekstrak berwujud pasta yang tertinggal pada dinding labu. Ekstrak pasta kemudian diambil dengan menggunakan spatula kemudia ditimbang beratnya dan disimpan dalam botol vial gelap.

Pemeriksaan kandungan metabolit sekunder yang dilakukan merupakan uji skrining kualitatif yang digunakan untuk mengetahui ada atau tidaknya $( \pm)$ kandungan senyawa metabolit sekunder pada ekstrak murni daun tembelekan. Pemeriksaan kandungan metabolit sekunder yang dilakukan terdiri dari pemeriksaan saponin, tanin, alkaloid, fenolik, flavonoid, triterpenoid, steroid, dan glikosida.

\section{Uji Hambat Tumbuh Bakteri}

Uji hambat tumbuh bakteri penyebab penyakit ice-ice pada rumput laut dilaksanakan secara in vitro dan secara kohabitasi in vivo pada wadah terkontrol.

\section{Pengujian in vitro (Lay, 1994)}

Prosedur uji aktivitas hambat tumbuh bakteri secara in vitro yang digunakan adalah metode KirbyBauer pada tes yang berbeda, yang ditunjukkan dengan adanya zona bebas/hambat di sekitar kertas cakram. Konsentrasi ekstrak yang digunakan pada pengujian in vitro ini adalah 5 (lima) konsentrasi ekstrak yaitu 1000 ppm, 1500 ppm, 2000 ppm, 5000 ppm, dan 10000 ppm dengan masing-masing 3 (tiga) kali pengulangan. Sebagai pembanding digunakan kontrol positif kloramfenikol $30 \mathrm{ppm}$ dan kontrol negatif menggunakan akuabides. Bakteri diinkubasi dalam inkubator dengan suhu $30{ }^{\circ} \mathrm{C}$ lalu diamati daya hambatnya setelah 24 jam.

\section{Pengujian kohabitasi in vivo dalam akuarium}

Pengujian kohabitasi dilakukan untuk melihat tingkat penularan bakteri penyebab penyakit dari rumput laut yang terserang penyakit ice-ice terhadap rumput laut sehat yang sebelumnya telah dilakukan perlakuan perendaman ke dalam larutan ekstrak daun tembelekan konsentrasi 2000 ppm dengan masingmasing perlakuan lama perendaman yang berbeda yaitu 30 menit (Perlakuan A), 60 menit (Perlakuan B), dan 90 menit (Perlakuan C) serta kontrol positif (Perlakuan D) dan kontrol negatif (Perlakuan E) dengan masing-masing 3 (tiga) kali pengulangan. Penentuan kondisi kesehatan rumput laut berdasarkan tanda-tanda klinis secara makrokopis, yang ditandai dengan terlihatnya bercak warna putih (klorosis) pada thallus rumput laut. Waktu pengamatan berat rumput laut dilakukan sebanyak 3 (tiga) kali pengamatan. Sampel yang digunakan adalah bibit rumput laut dengan berat basah $20 \mathrm{~g}$ pada masing-masing perlakuan, begitupun juga dengan berat basah rumput laut yang terserang penyakit ice-ice yang digunakan dalam pengamatan ini. Pengujian kohabitas yang dilakukan secara in vivo ini menggunakan wadah akuarium berukuran $45 \times 30 \times 30 \mathrm{~cm}$ dengan volume air media air laut adalah 501 .

\section{Hasil}

\section{HASIL DAN PEMBAHASAN}

\section{Kandungan metabolit sekunder}

Pemeriksaan ini dilakukan untuk mengetahui kandungan senyawa metabolit sekunder dalam suatu bahan secara kualitatif. Ekstrak daun tembelekan yang diuji positif mengandung saponin, tanin, fenolik, flavonoid, steroid, dan glikosida. Hasil pengujian kualitatif dapat dilihat pada Tabel 1 .

Tabel 1. Hasil pemeriksaan fitokimia daun tembelekan.

\begin{tabular}{clcl}
\hline No. & $\begin{array}{c}\text { Jenis } \\
\text { pemeriksaan }\end{array}$ & $\begin{array}{c}\text { Hasil } \\
\text { pemeriksaan }\end{array}$ & $\begin{array}{c}\text { Metode } \\
\text { pemeriksaan }\end{array}$ \\
\hline 1. & Saponin & + & Kualitatif \\
2. & Tanin & + & Kualitatif \\
3. & Alkaloid & - & Kualitatif \\
4. & Fenolik & + & Kualitatif \\
5. & Flavonoid & + & Kualitatif \\
6. & Triterpenoid & - & Kualitatif \\
7. & Steroid & + & Kualitatif \\
8. & Glikosida & + & Kualitatif \\
\hline
\end{tabular}

\section{Pengujian in vitro}

Uji in vitro ekstrak daun tembelekan terhadap bakteri $V$. alginolyctus memperlihatkan bahwa ekstrak tersebut memiliki aktivitas sebagai anti bakteri. Adanya aktivitas anti bakteri tersebut ditunjukkan dengan terbentuknya zona daya hambat di sekitar paper disc pada masing-masing perlakuan (Gambar 1). Ekstrak murni daun L. camara mampu menghambat pertumbuhan bakteri $V$. alginolyctus penyebab penyakit ice-ice. 


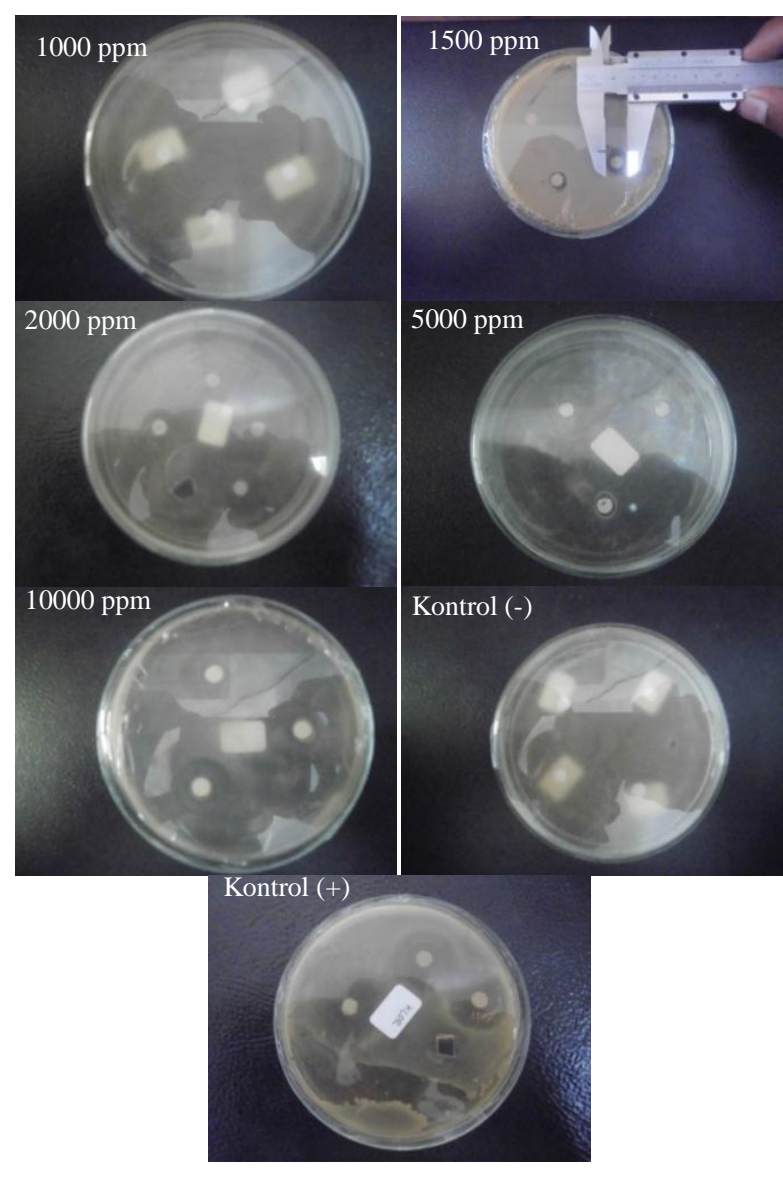

Gambar 1. Diameter zona hambat ekstrak murni daun tembelekan terhadap pertumbuhan bakteri V. alginolyctus

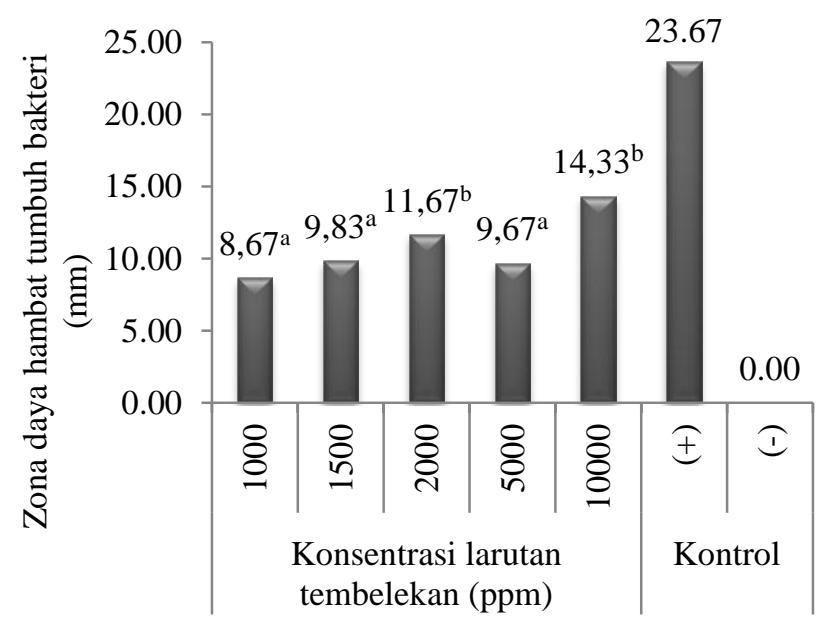

Gambar 2. Grafik diameter rata-rata zona daya hambat tumbuh bakteri pengujian secara in vitro, pada masing-masing konsentrasi larutan ekstrak serta kontrol positif dan negatif.
Berdasarkan hasil pengamatan, ekstrak murni daun tembelekan $L$. camara yang mempunyai ratarata diameter zona daya hambat terbesar ditunjukkan pada konsentrasi $10000 \mathrm{ppm}$ yaitu $14,33 \mathrm{~mm}$, lalu berturut-turut diikuti oleh konsentrasi 2000 ppm sebesar 11,67 mm, konsentrasi 5000 ppm sebesar 9,67 mm, konsentrasi $1500 \mathrm{ppm}$ sebesar 9,83 ppm dan terendah adalah pada konsentrasi $1000 \mathrm{ppm}$ yaitu $8,67 \mathrm{~mm}$. Sementara itu, tidak terdapat perbedaan diameter zona hambat yang signifikan antara konsentrasi 1500, dan 5000 ppm (Gambar 2).

Berdasarkan hasil analisis statistik T-Test, didapatkan hasil bahwa perbedaan yang nyata terhadap respon antara konsentrasi 10000 dan 2000 ppm dan konsentrasi 1000, 1500, dan 5000 ppm. Hasil yang tidak berbeda nyata terlihat antara konsentrasi 2000 dan 10000 ppm, serta antara konsentrasi 1000, 15000, dan 5000 ppm.

\section{Pengujian kohabitasi secara in vivo}

Perubahan morfologi thallus rumput laut dengan perlakuan A menunjukkan adanya perubahan morfologi khususunya klorosis yang terjadi pada pengamatan kedua (h3) dan pengamatan ketiga (h5). Perubahan morfologi thallus rumput laut selama 5 (lima) hari pengamatan diawali dengan semakin pucatnya warna thallus dibandingkan dengan kondisi awal perendaman dan pada pengamatan pertama (h1) yang menampakkan kondisi thallus dalam keadaan sehat. Kejadian tersebut berlangsung pada pengamatan kedua (h3) terlihat insiden klorosis pada 2 (dua) percabangan thallus. Percabangan thallus rumput laut uji yang terinfeksi terus mengalami klorosis dan banyak bagian yang patah (rapuh) sampai pada pengamatan ketiga (h5). Perubahan morfologi thallus rumput laut pada perlakuan 60 menit perendaman (B) selama 5 (lima) hari pengamatan mengalami kondisi yang cenderung tidak mengalami perubahan yang drastis. Perubahan diawali dengan munculnya gejala klorosis pada salahsatu percabangan thallus. Kondisi demikian berlanjut dengan semakin memudarnya warna thallus dari pengamatan pertama yang sehat (h1). Klorosis diamati mulai terjadi pada pengamatan kedua (h3). Selain terdapat klorosis juga terlihat ada percabangan thallus yang patah dan rontok ke dasar akuarium. Bila dibandingkan dengan perubahan yang terjadi pada perlakuan lainnya yaitu 30 dan 90 menit perendaman, klorosis yang ada pada perlakuan 60 menit perendaman ini diamati paling sedikit dan 
hanya terjadi pada satu titik bagian thallus bibit rumput laut. Perubahan morfologi thallus rumput laut pada perlakuan $\mathrm{C}$ dengan 5 (lima) hari pengamatan mengalami kondisi pertambahan klorosis pada thallus masing-masing pengamatan. Perubahan tersebut juga dapat dilihat dengan makin memudarnya warna thallus dari kondisi awal mula yang sehat. Pada pengamatan pertama dan kedua terlihat warna putih pada ujung thallus yang terjangkiti ice-ice masih terlihat sama. Klorosis pada ujung thallus makin terlihat bertambah seiring bertambahnya waktu kohabitasi, hal ini terlihat pada pengamatan ketiga (h5). Pada pengamatan terlihat area thallus yang terkena klorosis dan terserang ice-ice semakin luas penyebarannya hampir di setiap percabangan thallus. Hasil pengamatan secara visual terhadap perubahan morfologi thallus hasil pengujian kohabitasi disajikan pada Gambar 3. Sedangkan rata-rata hasil perubahan berat thallus bibit rumput laut disajikan pada Tabel 2 dan Gambar 4.

Hasil Anova terhadap perubahan berat basah thallus bibit rumput laut yang diujikan menunjukkan bahwa ketiga perlakuan saling memberikan respon pengaruh yang sangat berbeda nyata $(\operatorname{sig}<0,05)$.

Tabel 2.Rata-rata perubahan berat basah thallus bibit rumput laut selama pengujian.

\begin{tabular}{ccccc}
\hline \multirow{2}{*}{ Perlakuan } & \multicolumn{2}{c}{$\begin{array}{c}\text { Perubahan berat basah } \\
\text { thallus }(\mathrm{g})\end{array}$} & \multirow{2}{*}{$\begin{array}{c}\text { Rata- } \\
\text { rata }(\mathrm{g})\end{array}$} \\
\cline { 2 - 4 } & \multicolumn{3}{c}{ Pengamatan ke- } & \\
\cline { 2 - 4 } & $\mathbf{1}$ & $\mathbf{2}$ & $\mathbf{3}$ & \\
\hline $\mathrm{A}$ & 19.27 & 16.07 & 14.07 & 5,93 \\
$\mathrm{~B}$ & 19.70 & 18.60 & 17.53 & 2,47 \\
$\mathrm{C}$ & 18.60 & 14.57 & 12.20 & 7,80 \\
\hline
\end{tabular}

Hasil analisis statistik uji lanjut Tukey HSD yang didapatkan pada pengamatan pertama (h1), perendaman bibit selama 30 menit (perlakuan A) memberikan respon pertumbuhan yang tidak berbeda terhadap perendaman bibit selama 60 menit (perlakuan B), akan tetapi memberikan respon perlakuan yang berbeda nyata terhadap perlakuan perendaman selama 90 menit (perlakuan C),

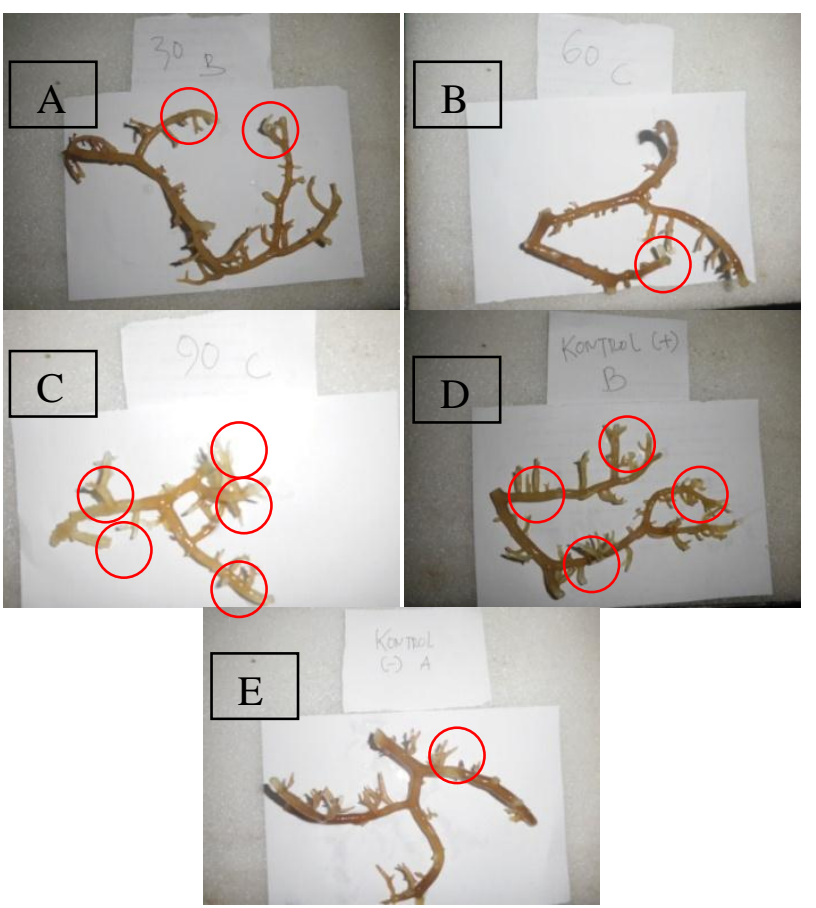

Gambar 2. Hasil tahapan perubahan warna thallus pada uji kohabitasi pada pengamatan terakhir dari perlakuan lama perendaman bibit; 30 menit (A); 60 menit (B); 90 menit (C), serta pada kontrol positif (+) dan negatif (-).

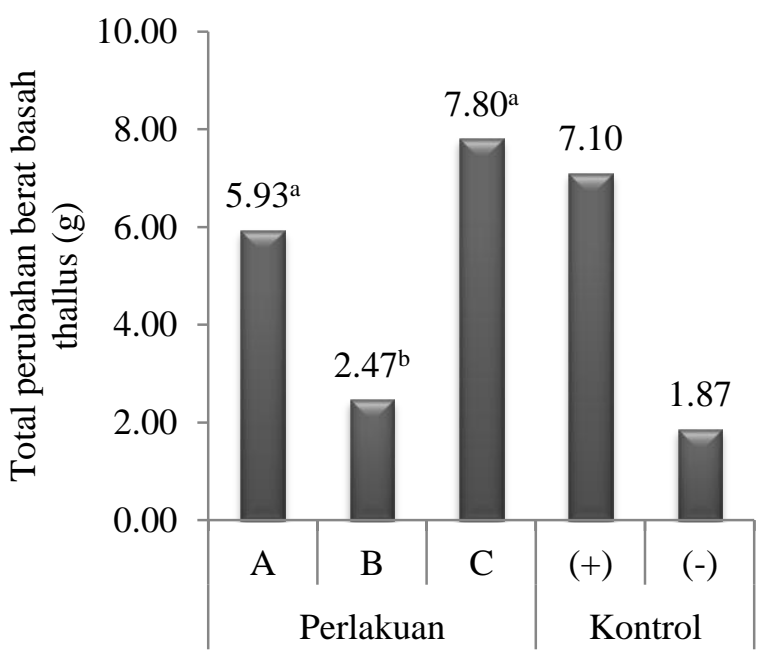

Gambar 4.Histogram hasil pengamatan total perubahan berat basah thallus rumput laut uji kohabitasi pada pengamatan terakhir dari perlakuan lama perendaman bibit; 30 menit (A); 60 menit (B); 90 menit (C), serta pada kontrol positif (+) dan negatif (-). 
begitupun dengan perlakuan perendaman bibit selama 60 menit (perlakuan B) terhadap perendaman bibit selama 90 menit (perlakuan C).

Hasil pada pengamatan kedua (h3), perlakuan perendaman bibit selama 30 menit (perlakuan A) memberikan respon yang tidak berbeda nyata terhadap 2 (dua) perlakuan lainnya yaitu perendaman selama 60 dan 90 menit. Perlakuan yang memberikan respon berbeda nyata adalah perlakuan perendaman selama 60 menit (perlakuan B) terhadap perendaman selama 90 menit (perlakuan C). Hasil yang didapatkan pada pengamatan ketiga (h5), perlakuan yang memberikan respon yang tidak berbeda nyata terlihat antara perlakuan perendaman selama 30 menit (perlakuan A) dan perendaman selama 90 menit (perlakuan C), sedangkan perlakuan yang memberikan respon hasil yang berbeda nyata adalah perendaman selama 60 menit (perlakuan B) terhadap perendaman selama 90 menit (perlakuan C).

\section{Pembahasan}

\section{Kandungan metabolit sekunder}

Aktivitas anti bakteri disebabkan oleh kandungan bahan alam yang ada di dalam ekstrak intraseluler. Keberadaan metabolit sekunder digunakan hewan atau tumbuhan untuk mempertahankan kelangsungan hidupnya misalnya; toksin, antibiotik, antijamur, antivirus, antibodi dan lainnya (Sunarminingsih, 2002). Hasil pemeriksaan fitokimia ekstrak murni daun tembelekan mengandung senyawa metabolit sekunder steroid dan saponin. Menurut Cowan (1999), steroid memiliki mekanisme penghambatan bakteri dengan merusak membran sel bakteri dengan meningkatkan permeabilitas sel, sehingga terjadi kebocoran sel yang diikuti keluarnya material. Saponin bekerja sebagai anti bakteri dengan mengganggu stabilitas membran sel bakteri sehingga menyebabkan sel bakteri lisis dan keluarnya berbagai komponen penting dari dalam sel seperti protein, asam nukleat dan nukleotida. Sementara itu, dengan adanya senyawa metabolit sekunder dalam ekstrak maka pembentukan dinding sel bakteri menjadi terganggu. Akibatnya Vibrio tidak mampu mereplikasi diri dan tumbuh dalam media agar (Ganiswarna, 1995).

\section{Pengujian in vitro}

Secara visual zona hambat yang terbentuk pada konsentrasi 1000, 1500, dan 5000 ppm tidak jernih atau masih terdapat beberapa koloni bakteri. Zona hambat terlihat sangat jelas pada konsentrasi 2000 dan 10000 ppm dimana tidak terlihat koloni bakteri tumbuh di dalamnya. Sedangkan pada perlakuan kontrol positif, zona hambat yang terbentuk sangat jernih. Zona hambat yang terlihat bersih disebut dengan zona hambat radikal dimana sama sekali tidak terdapat adanya pertumbuhan bakteri sedangkan zona hambat yang ditumbuhi bakteri disebut dengan zona hambat iradikal karena pada daerah tersebut pertumbuhan bakteri dihambat namun tidak sampai mati (Sulistyawati $d k k$., 2009).

Mengacu pada Ganjewala, $d k k$. (2009), aktivitas senyawa anti bakteri yang terkandung dalam L. camara memiliki aktivitas yang sedang hingga kuat karena berada pada kisaran diameter zona hambat sebesar 9-15 mm. Aktivitas anti bakteri dari ekstrak tembelekan tidak lebih besar dibandingkan dengan kontrol positifnya yaitu antibiotik kloramfenikol sebesar $30 \mathrm{ppm}$. Hal tersebut dikarenakan kloramfenikol merupakan senyawa murni.

Anti bakteri dapat diklasifikasikan menjadi bakteriostatik dan bakteriosidal. Bakteriostatik yaitu kemampuan anti bakteri dalam menghambat pertumbuhan bakteri, tetapi tidak sampai membunuh bakteri. Bakterisidal yaitu anti bakteri memiliki kemampuan untuk membunuh bakteri. Cara kerja anti bakteri secara umum yaitu menyebabkan kerusakan dinding sel, mengubah permeabilitas sel, mengubah molekul protein dan asam nukleat, menghambat kerja enzim serta menghambat sintesis asam nukleat dan protein (Pelczar dan Chan, 2005).

Aktivitas anti bakteri dari ekstrak murni daun tembelekan bersifat bakteriostatik karena zona daya hambat yang terbentuk pada hampir seluruh perlakuan masih terlihat adanya koloni bakteri yang tumbuh. Ekstrak yang dibuat dalam penelitian merupakan ekstrak kasar dimana masih banyak terdapat beberapa komponen kimia yang tidak dibutuhkan seperti lipid dan pigmen yang terekstrak oleh pelarut etanol. Hal tersebut menurunkan kemurnian dari senyawa anti bakteri.Aktivitas anti bakteri dari ekstrak murni daun tembelekan bersifat bakteriostatik yaitu kemampuan anti bakteri dalam menghambat pertumbuhan bakteri, tetapi tidak sampai membunuh bakteri, karena zona daya hambat yang terbentuk pada hampir seluruh perlakuan masih terlihat adanya koloni bakteri yang tumbuh. 


\section{Pengujian kohabitasi secara in vivo}

Berdasarkan pengamatan yang dilakukan secara visual terhadap perubahan morfologi maupun berat basah thallus hasil pengujian kohabitasi maka diperoleh hasil bahwa dari perendaman bibit selama 60 menit (perlakuan B) memberikan hasil yang paling baik dibandingkan dengan 2 (dua) perlakuan lainnya, yaitu lama perendaman bibit selama 30 dan 90 menit. Gejala klinis yang ditunjukkan oleh thallus rumput laut yang terserang penyakit ice-ice diawali dengan perubahan warna thallus (memucat), timbulnya bercak putih pada thallus dan akhirnya thallus menjadi keropos hingga patah.

Tigkat keberhasilan masing-masing pengujian kohabitasi sampai mengarah ke gejala penyakit iceice ini sangat dipengaruhi oleh luasnya daerah sebaran thallus yang terinfeksi dan pemutihan (klorosis). Proses pemutihan yang terjadi mempunyai hubungan dengan keberadaan bakteri patogen yang berhasil ditransmisikan dari thallus bibit rumput laut yang terjangkit penyakit ice-ice dan mengalami klorosis pada pengujian kohabitasi ini. Hal tersebut sejalan dengan pernyataan dari hasil penelitian Largo dkk. (1995) yang menunjukkan bahwa proses penurunan substansi organik pada thallus diakibatkan oleh pemanfaatan substansi tersebut oleh bakteri yang menyebabkan rumput laut dengan mudah terinfeksi penyakit ice-ice.

\section{KESIMPULAN}

Kandungan metabolit sekunder pada daun tembelekan dapat menghambat pertumbuhan bakteri $V$. alginolyctus penyebab penyakit ice-ice pada thallus rumput laut dan bersifat bakteriostatik pada pada pengujian secara in vitro. Tingkat patogenisitas bakteri paling rendah terhadap jaringan rumput laut pada pengujian kohabitas adalah dengan lama perendaman bibit selama 60 menit, bila dibandingkan dengan perendaman selama 30 dan 90 menit.

Ucapan Terima Kasih : Penulis menyampaikan terima kasih kepada analis laboratorium pada Balai Penelitian Tanaman Rempah dan Obat Bogor serta Laboratorium Perikanan F-PIK UHO Kendari. Terima kasih juga disampaikan kepada semua pihak yang telah memberikan bantuan dan fasilitas dalam penyusunan artikel ilmiah ini.

\section{DAFTAR PUSTAKA}

Aris M. 2011. Identifikasi, Patogenisitas Bakteri dan Pemanfaatan Gen 16S-rRNA untuk Deteksi Penyakit Ice-Ice pada Budidaya Rumput Laut Kappaphycus alvarezii. [Disertasi]. Program Pascasarjana. Institut Pertanian Bogor.

Barreto FS., Sousa EO., Campos AR., Costa JGM., Rodrigues FFG. 2010. Antibacterial activity of Lantana camara Linn and Lantana montevidensis Brig extracts from Cariri-Ceará, Brazil. Journal of Young Pharmacists. 2 (1):42$44 \mathrm{p}$.

Cowan MM. 1999. Plant Products as Antimicrobial Agents. Department of Microbiology Miami University. Microbiological Reviews. 564-582 p.

DJPB. 2010. Data Statistik Series Produksi Perikanan Budidaya Indonesia. Kementerian Kelautan dan Perikanan Republik Indonesia. Jakarta.

Ganjewala D., Sam S., and Khan KH. 2009. Biochemical compositions and antibacterial activities of Lantana camara plants with yellow, lavender, red and white flowers. EurAsian Journal of BioSciences. 3:69-77 p.

Harborne JB. 1987. Metode Fitokimia: Penuntun Cara Modern Menganalisa Tumbuhan, Terjemahan Kosasih P dan Iwang SJ. Penerbit ITB. Bandung.

KKP. 2014. Kelautan Dan Perikanan Dalam Angka. Pusat Data Statistik Dan Informasi Kementerian Kelautan Dan Perikanan Republik Indonesia. Jakarta.

Largo DB., Fukami K., and Nishijima T. 1995. Occasional pathogenic bacteria promoting ice-ice disease in the Carrageenan- producing red algae Kappaphycus alvarezii and Euchema denticulatum (Solieriaceae, Gigartinales, Rhodophyta). Journal of Applied Phycology 7: 545-554 p.

Lay BW. 1994. Analisis Mikroba di Laboratorium. PT. Rajagrafindo Persada, Jakarta.168 hal.

Pelczar MJ., dan Chan. 2005. Dasar-Dasar Mikrobiologi 2. Hadieoetomo RS Imas T, Tjitrosomo SS, Angka SL. Penerjemah: Jakarta. UI Press Terjemahan dari: Elements of Microbiology.

Sulistyawati, Dewi dan Mulyati S. 2009. Uji Aktivitas Antijamur Infusa Daun Jambu Mete (Anacardium occidentale, L) Infuse on Candida albians. Biomedika, 2(1) ISSN 1979-35. 
Sumarminingsih, R. 20002. Metabolit Sekunder: Manfaat dan Perkembangannya Dalam Dunia Farmasi. Pidato pengukuhan Jabatan Guru Besar pada Fakultas Farmasi Universitas Gadjah Mada.

Vairappan CS. 2006. Seasonal occurrences of epiphytic algae on the commercially cultivated red alga Kappaphycus alvarezii (Solieriaceae,
Gigartinales, Rhodophyta). J. Appl. Phycol. 18: 611-617 hal.

Vaseeharan B., Prasad GS., Ramasamy P. and Brennan G. 2011. Antibacterial activity of Allium sativum against multidrug-resistant Vibrio harveyi isolated from black gilldiseased Fenneropenaeus indicus. Aquacult Int. 19:531539 p. 